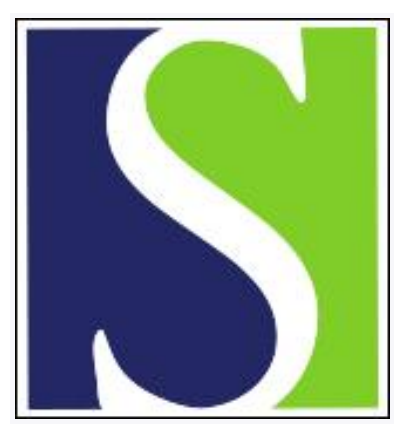

Scand J Work Environ Health 2001;27(4):250-257

https://doi.org/10.5271/sjweh.612

Issue date: Aug 2001

Effects of blasting fumes on exposure and short-term lung function changes in tunnel construction workers

by Bakke B, Ulvestad B, Stewart P, Lund MB, Eduard W

Affiliation: National Institute of Occupational Health, PO Box 8149 Dep, N-0033 Oslo, Norway. bba@stami.no

The following article refers to this text: 2007;33(2):114-122

Key terms: alpha-quartz; blasting fumes; diesel exhaust; explosive; exposure; lung function change; nitrogen dioxide; tunnel construction worker

This article in PubMed: www.ncbi.nlm.nih.gov/pubmed/11560339 


\title{
Effects of blasting fumes on exposure and short-term lung function changes in tunnel construction workers
}

\author{
by Berit Bakke, MSc, ${ }^{1}$ Bente Ulvestad, MD, ${ }^{2}$ Patricia Stewart, PhD, ${ }^{3}$ May Brit Lund, PhD, ${ }^{4}$ Wijnand \\ Eduard, $P h D^{1}$
}

\begin{abstract}
Bakke B, Ulvestad B, Stewart P, Lund MB, Eduard W. Effects of blasting fumes on exposure and short-term lung function changes in tunnel construction workers. Scand J Work Environ Health 2001;27(4):250-257.
\end{abstract}

\begin{abstract}
Objectives This study attempts to determine the effects of exposure to blasting fumes and its influence on the lung function of tunnel workers.

Methods Two groups of tunnel workers, one using ammonium nitrate fuel oil (ANFO) as the explosive and the other using size-sensitized emulsion (SSE), with 24 workers per group, were compared with a reference group $(\mathrm{N}=34)$ with low exposure. Spirometry was used to determine lung function. Personal exposure to total and respirable dust, alpha-quartz, volatile organic compounds, oil mist and vapors, formaldehyde, nitrogen dioxide, and carbon monoxide was measured.

Results The ANFO workers were more exposed to all the agents than the reference group and more exposed than the SSE workers to all the agents except total dust and carbon monoxide. The SSE workers were significantly more exposed to total dust and alpha-quartz than the reference group. High peak exposures to nitrogen dioxide (up to $20 \mathrm{ppm}$ ) occurred for the ANFO workers in contrast to the SSE workers, whose exposure did not exceed $2 \mathrm{ppm}$. The lung function of the ANFO workers significantly decreased by $3 \%$ for forced vital capacity, $7 \%$ for forced expiratory volume in 1 second, and $8 \%$ for forced expiratory flow rate from $25 \%$ to $75 \%$ of the forced vital capacity over the 11-day period. The changes were reversible. There were no significant changes among the SSE workers and the outdoor workers. The ANFO workers had a significant decrease in $\mathrm{FEV}_{1.0}$ when compared with both the SSE and outdoor workers.

Conclusions Tunnel workers using ANFO explosive show a temporary reduction in lung function, whereas those using SSE do not. The most likely explanation for the observed changes is peak exposures to nitrogen dioxide.
\end{abstract}

Key terms alpha-quartz, explosives, diesel exhaust, nitrogen dioxide.

Tunnel construction workers are exposed to such agents as diesel exhaust, nitrogen dioxide, alpha-quartz, and oil mist, and the exposure may place them at increased risk for lung disorders $(1-5)$. Respiratory disease has been diagnosed for tunnel workers, but it is not clear which exposures cause the effects (6). Several agents could be implicated (7-20).

In a previous study we found that tunnel workers were at increased risk of obstructive pulmonary disease (6) and that nonsmoking workers with no previous work experience in tunnels showed signs of upper and lower airway inflammation after 1 year of exposure to dusts and gases in tunnel work (21). Little is known about effects associated with shorter durations of exposure. In Norway, construction workers work 2 weeks consecutively and are then off the 3rd week. We were therefore able to study lung function changes over a 2-week work period. The introduction of a new type of explosive also gave us the opportunity to study the role of exposure to two types of blasting fumes on lung function.

The objectives of this study were to determine (i) short-term changes in lung function among tunnel

1 National Institute of Occupational Health, Oslo, Norway.

2 Selmer ASA, Oslo, Norway.

3 National Cancer Institute, Rockville, Maryland, United States.

4 Department of Thoracic Medicine, The National Hospital, University of Oslo, Norway.

Reprint requests to: Berit Bakke, National Institute of Occupational Health, PO Box 8149 Dep, N-0033 Oslo, Norway. [Email:bba@stami.no] 
workers and (ii) the influence of exposure to blasting fumes on lung function.

\section{Materials and methods}

\section{Site selection and characteristics}

Four Norwegian tunneling construction sites were included in the study to assess the personal exposure and lung function changes of tunnel construction workers and outdoor workers.

The four tunnels can be characterized as follows: at two of the sites with cross-sections of $61 \mathrm{~m}^{2}$ and $111 \mathrm{~m}^{2}$, ammonium nitrate fuel oil (ANFO) (Dyno Nobel Europe, Norway) was used as the explosive. At the other two sites, with cross-sections of $50 \mathrm{~m}^{2}$ and $65 \mathrm{~m}^{2}$, size-sensitized emulsion (SSE) (Dyno Nobel Europe, Norway) was used. SSE is an emulsion consisting of an aqueous nitrate solution and an oil phase that is mixed with a chemical sensitizer. The emulsion becomes explosive after a few minutes in the drill hole. Historically, the most common explosive used in tunneling is ANFO. In recent years, SSE, which had earlier been used only in open air, has been used in underground excavation. In all four tunnels, fresh air was supplied to the tunnel face through flexible ventilation ducts at a rate of $1400-2500 \mathrm{~m}^{3} / \mathrm{min}$. The blasting fumes were not mechanically removed by exhaust ventilation but were, instead, aired out through the tunnel cavity. The transport and hauling equipment was diesel-powered and the drilling equipment was electrically powered. The same types of equipment were used in all the tunnels.

\section{Subjects and job description}

The following three groups of workers were studied: two groups of tunnel workers, one using either the explosive ammonium nitrate fuel oil (ANFO) and the other working with size-sensitized emulsion (SSE), and a reference group of other construction workers with low exposure to diesel exhaust and no exposure to blasting fumes.

A detailed description of the job categories has been reported elsewhere (1). Tunnel work follows a sequence that starts with drilling holes into the rock for the placement of explosives. After blasting, workers transport the broken rock out of the tunnel and take care of various support work, in particular the installation and maintenance of ventilation ducting, cables, and pipes. In addition, workers carry out service work on equipment in the tunnel. Except for the different explosives used, there were no differences between the type and duration of tasks performed by the two groups of tunnel workers (ANFO and SSE).

The reference group consisted of ironworkers and carpenters doing concrete construction outside of the tunnel. The ironworkers first erect steel reinforcement bars. The carpenters then construct a wood form around the bars and spray the form with mineral oil. They pour moist concrete into the wood form and allow it to harden. The wood form is then demolished. The concrete surface is occasionally sandblasted to provide a smooth surface. The reference group is hereafter referred to as outdoor workers.

\section{Medical survey}

All ANFO and SSE workers (24 in each group) employed at the four tunnel construction sites were invited to participate in this 2-week follow-up study. In addition, all the outdoor workers from the two ANFO sites were included as a reference group $(\mathrm{N}=34)$. All the medical tests were carried out at the worksites. To ensure $100 \%$ participation, the health service team returned to the sites several times until all the workers were examined. The health data were collected over the same period as the exposure measurements.

All the participants worked one 6-day week, followed by 1 day off before working one 5-day week. After the 2week period they were off for 10 days. The workshift was 10 hours long with 2 breaks of 30 minutes each. The demographic data of the study subjects are given in table 1 .

Table 1. Characteristics of the study population stratified by job category. (ANFO = ammonium nitrate fuel oil, SSE = size sensitized emulsion)

\begin{tabular}{|c|c|c|c|c|c|c|c|c|c|c|c|c|c|c|}
\hline \multirow[t]{3}{*}{ Job group } & \multirow{2}{*}{\multicolumn{2}{|c|}{ Age (years) }} & \multirow{2}{*}{\multicolumn{2}{|c|}{ Height (cm) }} & \multirow{2}{*}{\multicolumn{2}{|c|}{ Weight (kg) }} & \multicolumn{6}{|c|}{ Smoking status } & \multirow{2}{*}{\multicolumn{2}{|c|}{$\begin{array}{l}\text { Positive Phadiatop } \\
\text { test }\end{array}$}} \\
\hline & & & & & & & \multicolumn{2}{|c|}{ Former smokers } & \multicolumn{2}{|c|}{ Never smokers } & \multicolumn{2}{|c|}{ Current smokers } & & \\
\hline & Mean $^{a}$ & SD & Mean $^{a}$ & SD & Mean $^{a}$ & SD & $\mathrm{N}$ & $\%$ & $\mathrm{~N}$ & $\%$ & $\mathrm{~N}$ & $\%$ & $\mathrm{~N}$ & $\%$ \\
\hline ANFO workers $(\mathrm{N}=24)$ & 41 & 10 & 182 & 6.5 & 84 & 7.0 & 5 & 21 & 6 & 25 & 13 & 54 & 2 & 8 \\
\hline SSE workers $(\mathrm{N}=24)$ & 48 & 9.9 & 180 & 6.5 & 85 & 11 & 4 & 17 & 6 & 25 & 14 & 58 & 4 & 17 \\
\hline Outdoor workers $(\mathrm{N}=34)$ & 36 & 9.4 & 179 & 6.2 & 80 & 7.9 & 6 & 18 & 10 & 29 & 18 & 53 & 6 & 18 \\
\hline
\end{tabular}

a Arithmetic mean. 
The study was approved by the National Data Inspectorate and the Regional Medical Board of Ethics.

\section{Exposure assessment}

Sampling strategy. Measurements were carried out at both ANFO sites and the SSE site with the cross-section of $65 \mathrm{~m}^{2}$ between March 1996 and March 1997. A random sample of workers from the three groups (ANFO, SSE and outdoor) was asked to participate in the exposure assessment. Because of sampling constraints no attempt was made to include only the workers in the medical study. Participation was on a voluntary basis, but all the selected workers decided to participate.

Exposure to dust and gases was determined by means of personal sampling and two or more agents were measured simultaneously for each person for at least 2 days.

The sampling duration was $5-8$ hours (unless otherwise noted) because of the limited battery capacity of the sampling equipment and the high dust load on the filters. The sampling time was considered representative of the whole workshift because the sampling periods within the shift were selected randomly and the tasks were often repeated within the day.

Sampling methods and analysis. The methods used for the sampling and analyses have been described in detail elsewhere (1). Total dust was collected on acrylic copolymer membrane filters in standard aerosol monitors. The particle mass was measured by gravimetry. An adsorbent (XAD-2) filled the space behind the filter for collecting volatile organic compounds. Volatile organic compounds were measured by gas chromatography (GC) with a flame ionization detector (FID). Respirable dust was collected on cellulose acetate filters using British Casella cyclone separators. The particle mass was measured by gravimetry, and the alpha-quartz content of the respirable dust fraction was measured by $\mathrm{X}$ ray diffraction. Formaldehyde was collected on a filter impregnated with 2,4-dinitrophenylhydrazine in a polypropylene housing. Formaldehyde was analyzed by high-performance liquid chromatography with an ultraviolet detector. Oil mist was collected on glass fiber filters with a backup filter of cellulose acetate in closed faced aerosol cassettes and measured by fourier transform infrared spectroscopy. Oil vapors were collected using charcoal tubes and measured by GC-FID. The oil mist and oil vapors were sampled for $2-4$ hours. The carbon monoxide and nitrogen dioxide concentrations were measured with direct-reading electrochemical sensors with a data-logging facility built into the instrument (type Neotox-xl personal single-gas monitor, Neotron- ics Limited, Takeley, England). An averaging period of one reading every 2 minutes was selected.

\section{Assessment of respiratory health effects}

Spirometric tests. The lung function tests were performed shortly before the workshift on the first day back on site after 10 days off. After 11 days of work, the lung function tests were performed again at the same time of day. For the study of temporary lung function changes, workers with a $>10 \%$ decrease in their forced expiratory volume in 1 second $\left(\mathrm{FEV}_{1.0}\right)$ were reexamined shortly before the first workshift after a second week off (10 days). Other workers were not reexamined due to study constraints. None of the subjects reported physician-diagnosed asthma, which was a criterion of exclusion from the study. All the participants had to be free from respiratory infections for 3 weeks prior to the testing.

The spirometric measurements were performed in a sitting position by the same two trained technicians using a pneumotachograph spirometer (Sensor Medic lab transfer, California, USA). The spirometer was calibrated daily with the use of a 3-liter syringe. The subject wore a nose clip during the test. The measurements were performed in accordance with the guidelines recommended by the American Thoracic Society (22). Room and spirometer temperature, as well as barometric pressure, were recorded. At least three flow volume tests were performed for each subject. The following variables were recorded: forced vital capacity (FVC), forced expiratory volume in 1 second $\left(\mathrm{FEV}_{1.0}\right)$, and forced expiratory flow rate from $25 \%$ to $75 \%$ of the FVC $\left(\mathrm{FEF}_{25-75}\right)$. The lung function variables were expressed in absolute values and as the percentage of the predicted value according to the reference values of the European Coal and Steel Community (ECSC) (23).

Immunoglobulin E measurements. Venous blood samples were drawn from all the subjects. The serum samples were frozen at $-70^{\circ} \mathrm{C}$. Screening for atopy was performed using Phadiatop (Pharmacia Diagnostics AB, Uppsala, Sweden), a multiple radioallergosorbent test of immunoglobulin (Ig) E against nine common respiratory allergens (birch, timothy, mugwort, Cladosporium herbarum, Alternaria tenuis, Dermatophagoides pteronyssinus, cat dander, dog epithelium, and horse dander) (24). Atopy was defined as a positive Phadiatop test.

Questionnaire. Information on age and smoking status was obtained from a general questionnaire used in an earlier cross-sectional study (6). The workers answered the questionnaire before the first examination. For the categorization of smoking status, the workers were classified as never smokers, former smokers, and current 
smokers. Former smokers were those who had stopped smoking more than 12 months earlier (table 1).

\section{Data analysis}

With the use of cumulative probability plots, the exposure data were found to be best described by log-normal distributions and were ln-transformed before further statistical analyses. The measured exposure values were used without further adjustment as they were regarded as representative of the whole workshift. Standard measures of central tendency and distributions [arithmetic (AM) and geometric means (GM) and geometric standard deviations (GSD)] were calculated. Kruskal Wallis tests were used to evaluate the differences in the exposure levels among the three job categories. Mann-Whitney tests were used for two-group comparisons for all the agents except nitrogen dioxide, for which the ANFO and SSE workers' exposure was compared with average ambient air levels by one-sample t-tests. The outdoor ambient air level was regarded as an estimate of the outdoor workers' exposure to nitrogen dioxide.

The change in lung function $\left(\Delta \mathrm{FVC}, \Delta \mathrm{FEV}_{1}\right.$, and $\left.\Delta \mathrm{FEF}_{25-75}\right)$ was defined as the difference between lung function at the start of the work period (after 10 days off) and the lung function at the end of the work period (after 11 days of work). Individual lung function changes were evaluated by comparing the lung function before and after the work period using paired t-tests. The relationship between the changes in lung function and job category was tested by a one-way analysis of variance with Bonferroni post hoc tests. Potential confounders (ie, age, height, smoking status, and atopy) were evaluated for their effect using a multiple linear regression.

Statistical analyses were carried out with SYSTAT 9.0 and SPSS 9.0 (SPSS Inc, Chicago, Ilinois, United States).

\section{Results}

\section{Exposure}

A total of 31 tunnel workers and 20 outdoor workers participated in the exposure study, and most $(82 \%)$ were monitored on more than one occasion.

The ANFO workers had significantly higher exposures than the outdoor workers for all the measured agents $(\mathrm{P}<0.001$ for total dust, respirable dust, aphaquartz, volatile organic compounds and oil mist, $\mathrm{P}<0.01$ for oil vapors and formaldehyde, and $\mathrm{P}<0.05$ for nitrogen dioxide) (table 2). When the ANFO workers were compared with the SSE workers, the ANFO workers had a statistically higher exposure to all the measured agents ( $\mathrm{P}<0.01$ for respirable dust, alpha-quartz, volatile organic compounds and oil vapors and $\mathrm{P}<0.05$ for nitrogen dioxide and oil mist) except for total dust $(\mathrm{P}=0.4)$ and carbon monoxide $(\mathrm{P}=0.1)$. The SSE workers were significantly more exposed to total dust $(\mathrm{P}<0.05)$ and alpha-quartz $(\mathrm{P}<0.01)$ than the outdoor group. None of the workers used a respirator during the workshift.

Although the geometric mean exposure of nitrogen dioxide was less than $1 \mathrm{ppm}$ for the ANFO workers, this group was exposed to high peaks of nitrogen dioxide when passing through the blasting fumes as the blasted rock was transported out of the tunnel. The maximum observed peak value was $20 \mathrm{ppm}$ for a 2-minute averaging period. The median of the exposure peaks was 3.5 $\mathrm{ppm}$, and the individual peaks ranged from 0.2 to 20 ppm (not shown). On the average, the ANFO workers experienced 11 exposure peaks (range $1-23$ ) over 2 ppm during a workshift, of which 1.4 peaks (range 0 4) were over $10 \mathrm{ppm}$. All told, $28 \%$ of the measurements performed for the ANFO workers showed exposure peaks of $>10 \mathrm{ppm}$. Figure 1 shows an example of nitrogen dioxide exposure during the transport of blasted rock after the use of the ANFO explosive. In contrast, the peak nitrogen dioxide exposures of the SSE workers did not exceed $2 \mathrm{ppm}$ throughout the sampling period as they passed through the blasting fumes. Figure 2 shows an example of the nitrogen dioxide exposure from the transport of blasted rock after the use of the SSE explosive.

\section{Clinical findings and lung function}

The SSE workers were older than the ANFO workers and the outdoor workers, but otherwise there were no major differences between the three groups with respect to height, weight, or smoking status (table 1). The prevalence of atopy was lower for the ANFO workers than for the two other groups. The covariates age, height, smoking status, and atopy had no significant influence on the associations and were therefore excluded from the models.

The results of the lung function tests are shown in table 3 . For the entire study group, the mean values of the $\mathrm{FVC}, \mathrm{FEV}_{1.0}$, and $\mathrm{FEF}_{25-75}$ at the start of the survey were $105 \%, 96 \%$ and $79 \%$ of the predicted values, respectively. There were no statistical differences between the groups for the before work values. The ANFO workers had a statistically significant decrease in $\mathrm{FEV}_{1.0}$ after 11 days of work when compared with the SSE workers $(\mathrm{P}<0.001)$ and the outdoor workers $(\mathrm{P}=0.002)$. There were no significant differences between the SSE workers and the outdoor workers. The lung function 
Table 2. Personal exposure levels of each job category by agent. (ANFO = ammonium nitrate fuel oil, SSE = size sensitized emulsion, $M=$ measured, $A A L=$ assumed to be ambient air level)

\begin{tabular}{|c|c|c|c|c|c|c|c|c|c|c|c|c|c|c|c|c|c|c|c|c|}
\hline \multirow[t]{2}{*}{ Job group } & \multicolumn{5}{|c|}{$\begin{array}{l}\text { Total dust } \\
\left(\mathrm{mg} / \mathrm{m}^{3}\right)\end{array}$} & \multicolumn{5}{|c|}{$\begin{array}{l}\text { Respirable dust } \\
\left(\mathrm{mg} / \mathrm{m}^{3}\right)\end{array}$} & \multicolumn{5}{|c|}{$\begin{array}{l}\text { alpha-Quartz } \\
\left(\mathrm{mg} / \mathrm{m}^{3}\right)\end{array}$} & \multicolumn{5}{|c|}{$\begin{array}{l}\text { Volatile organic compounds } \\
\left(\mathrm{mg} / \mathrm{m}^{3}\right)\end{array}$} \\
\hline & M & $\mathrm{P}$ & AM & GM & GSD & M & $\mathrm{P}$ & AM & GM & GSD & M & $\mathrm{P}$ & AM & GM & GSD & M & $\mathrm{P}$ & $\mathrm{AM}$ & GM & GSD \\
\hline ANFO workers & 52 & 23 & 2.2 & $1.7^{\mathrm{a}}$ & 2.2 & 54 & 23 & 1.0 & $0.73^{a, b}$ & 2.4 & 54 & 23 & 0.034 & $0.023^{a, b}$ & 3.1 & 52 & 23 & 5.6 & $3.1^{a, b}$ & 4.4 \\
\hline $\begin{array}{l}\text { SSE workers } \\
\text { Outdoor workers }\end{array}$ & $\begin{array}{l}11 \\
35\end{array}$ & $\begin{array}{r}5 \\
17\end{array}$ & $\begin{array}{l}1.7 \\
1.2\end{array}$ & $\begin{array}{l}1.5^{\mathrm{c}} \\
1.0^{\mathrm{a}, \mathrm{c}}\end{array}$ & $\begin{array}{l}1.6 \\
1.8\end{array}$ & $\begin{array}{r}9 \\
40\end{array}$ & $\begin{array}{r}5 \\
19\end{array}$ & $\begin{array}{l}0.29 \\
0.25\end{array}$ & $\begin{array}{l}0.26^{\mathrm{b}} \\
0.20^{\mathrm{a}}\end{array}$ & $\begin{array}{l}1.8 \\
1.7\end{array}$ & $\begin{array}{r}9 \\
40\end{array}$ & $\begin{array}{r}5 \\
19\end{array}$ & $\begin{array}{l}0.011 \\
0.003\end{array}$ & $\begin{array}{l}0.008^{\mathrm{b}, \mathrm{c}} \\
0.002^{\mathrm{a}, \mathrm{c}}\end{array}$ & $\begin{array}{l}2.6 \\
1.8\end{array}$ & $\begin{array}{l}11 \\
34\end{array}$ & $\begin{array}{r}5 \\
17\end{array}$ & $\begin{array}{l}1.3 \\
1.8\end{array}$ & $\begin{array}{r}1.2^{\mathrm{b}} \\
0.64^{\mathrm{a}}\end{array}$ & $\begin{array}{l}1.5 \\
7.6\end{array}$ \\
\hline Kruskal-Wallis, & \multicolumn{5}{|c|}{$P<0.01$} & \multicolumn{5}{|c|}{$P<0.001$} & \multicolumn{5}{|c|}{$P<0.001$} & \multicolumn{5}{|c|}{$P<0.001$} \\
\hline
\end{tabular}

a ANFO versus outdoor workers, Mann-Whitney test, $P \leq 0.05$, see the text for details.

${ }^{b}$ ANFO versus SSE workers, Mann-Whitney test, $P \leq 0.05$, see the text for details.

${ }^{c}$ SSE versus outdoor workers, Mann-Whitney test, $P \leq 0.05$, see the text for details

d Significantly different from the ambient air levels $(10-20 \mathrm{ppb}$, Norwegian Institute for Air Research, Kjeller, Norway) in the one-sample t-test, $\mathrm{P}<0.05$.

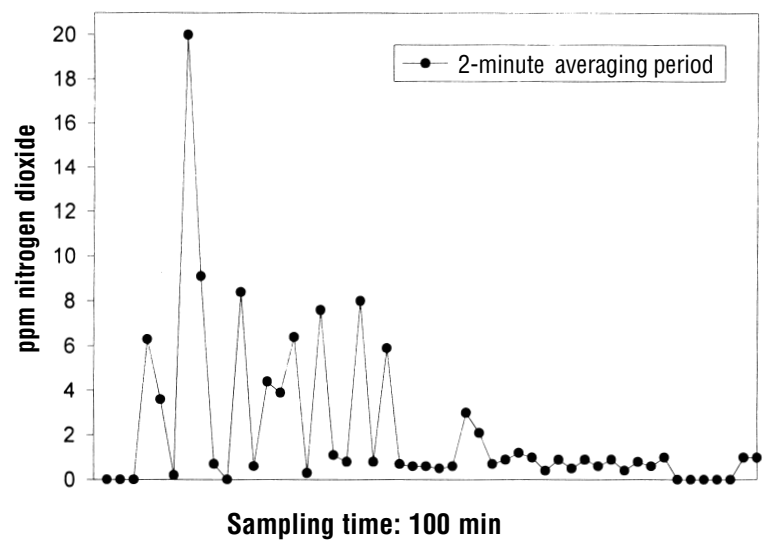

Figure 1. Example of nitrogen dioxide exposure during the transport of rock blasted with ammonium nitrate fuel oil (ANFO) as the explosive.

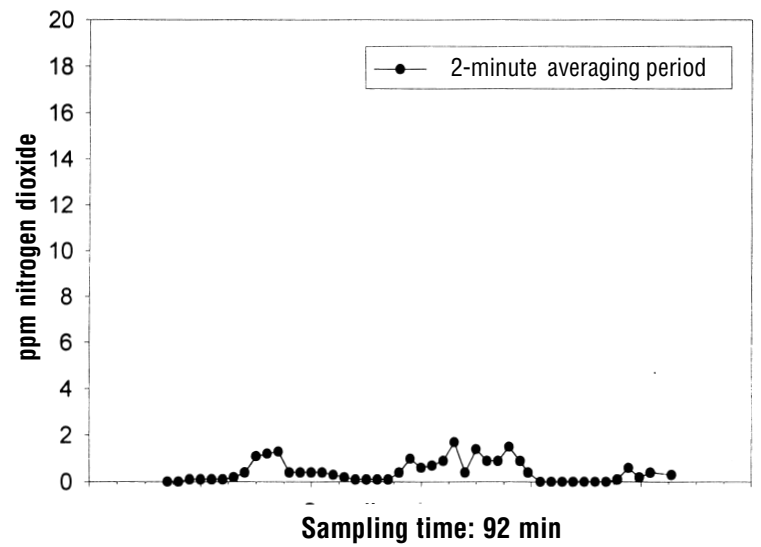

Figure 2. Example of nitrogen dioxide exposures during the transport of rock blasted with size-sensitized emulsion (SSE) as the explosive.

Table 3. Lung function of the workers in each job category and the lung function changes after 11 days of work. (FVC $=$ forced vital capadity, $\Delta=$ change , $\mathrm{FEV}_{1.0}=$ forced expiratory volume in 1 second, $\mathrm{FEF}_{25-75}=$ forced expiratory flow rate from $25 \%$ to $75 \%$ of the FVC, ANFO = ammonium nitrate fuel oil, SSE = size-sensitized emulsion, AM = arithmetic mean, SD = standard deviation)

\begin{tabular}{|c|c|c|c|c|c|c|c|c|c|c|c|c|c|c|c|}
\hline \multirow[t]{2}{*}{ Job group } & \multicolumn{2}{|c|}{$\begin{array}{l}\text { FVC (I) before } \\
\text { work }\end{array}$} & \multicolumn{3}{|c|}{$\Delta \mathrm{FVC}(\mathrm{I})$} & \multicolumn{2}{|c|}{$\begin{array}{l}\mathrm{FEV}_{1.0}(\mathrm{I}) \text { before } \\
\text { work }\end{array}$} & \multicolumn{3}{|c|}{$\Delta \mathrm{FEV}_{1.0}(\mathrm{l})$} & \multicolumn{2}{|c|}{$\begin{array}{l}\mathrm{FEF}_{25-75}(\mathrm{l} / \mathrm{s}) \\
\text { before work }\end{array}$} & \multicolumn{3}{|c|}{$\Delta \mathrm{FEF}_{25-75}(\mathrm{l} / \mathrm{s})$} \\
\hline & AM & SD & $A M$ & $\%$ & SD & AM & SD & AM & $\%$ & SD & AM & SD & AM & $\%$ & SD \\
\hline ANFO workers & 5.3 & 0.88 & $0.14^{a}$ & 3 & 0.26 & 3.9 & 0.69 & $0.27^{b, c, d}$ & 7 & 0.25 & 3.2 & 0.87 & $0.25^{\mathrm{e}}$ & 8 & 0.41 \\
\hline SSE workers & 5.0 & 0.77 & -0.018 & $<-1$ & 0.30 & 3.8 & 0.65 & $-0.082^{b}$ & -2 & 0.24 & 3.7 & 1.0 & 0.034 & 1 & 0.59 \\
\hline Outdoor workers & 5.4 & 0.79 & 0.081 & 2 & 0.26 & 4.1 & 0.65 & $0.0012^{c}$ & $<1$ & 0.33 & 3.6 & 0.93 & -0.093 & -3 & 0.56 \\
\hline One-way ANOVA, p & . & & 0.1 & & & . & & $<0.001$ & & & & & 0.05 & & \\
\hline
\end{tabular}

a Paired sample t-test, $P<0.05$.

b Pairs of significantly different means between job categories with Bonferroni post hoc tests $(P<0.01)$, ANF0 workers versus SSE workers.

c Pairs of significantly different means between job categories with Bonferroni post hoc tests $(P<0.01)$, ANFO workers versus outdoor workers.

d Paired sample t-test, $P<0.001$.

e Paired sample t-test, $\mathrm{P}<0.01$.

changes in the ANFO workers over the two measurement periods differed significantly from zero $\left(\triangle \mathrm{FEV}_{1.0}\right.$ $\mathrm{P}<0.001, \Delta \mathrm{FEF}_{25-75} \mathrm{P}<0.01$, and $\left.\Delta \mathrm{FVC} \mathrm{P}<0.05\right)$, but the corresponding changes in the two other groups were not significant. Eight ANFO workers and none of the other workers had a decrease in $\mathrm{FEV}_{1.0}$ of $>10 \%$ after 11 days of work. After 10 days off these values had returned to the baseline levels for all three parameters (not shown). 
number of measurements, $\mathrm{P}=$ number of persons, $\mathrm{AM}=$ arithmetic mean, $\mathrm{GM}=$ geometric mean, $\mathrm{GSD}=$ geometric standard deviation, $\mathrm{NM}=$ not

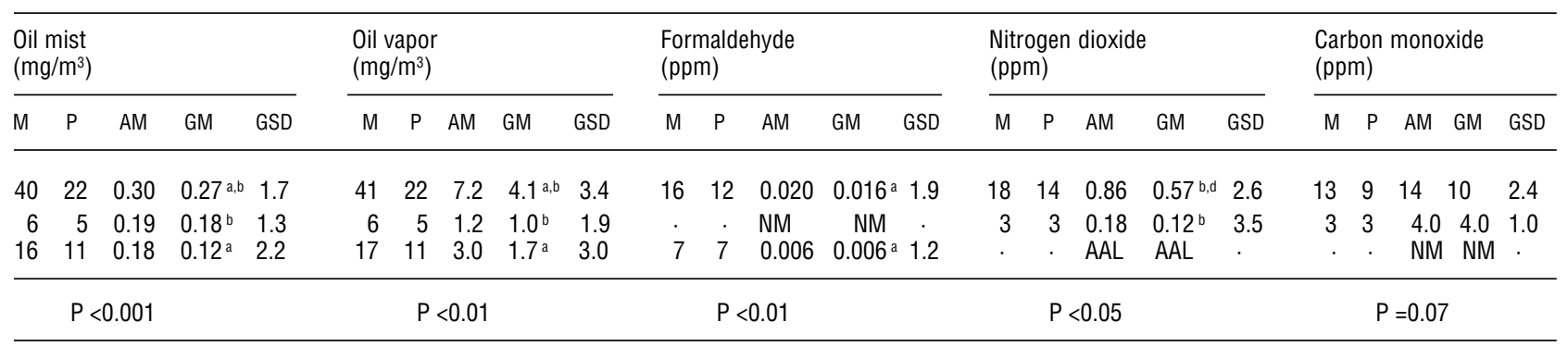

\section{Discussion}

In this study we investigated the lung function of tunnel workers exposed to the explosives ANFO and SSE and of ironworkers and carpenters working outside the tunnel after 11 days of work. The lung function of the ANFO workers decreased $3 \%$ for $\mathrm{FVC}, 7 \%$ for $\mathrm{FEV}_{1.0}$, and $8 \%$ for $\mathrm{FEF}_{25-75}$, and these differences were statistically significant. These changes were reversible, as the lung function of the eight workers who had a decrease in $\mathrm{FEV}_{1.0}$ of $>10 \%$ had returned to the baseline levels on reexamination after 10 days off. The SSE workers and the outdoor workers had changes in $\mathrm{FVC}, \mathrm{FEV}_{1.0}$, and $\mathrm{FEF}_{25-75}$ of $<3 \%$, which was within the expected variation (22). Potential confounders, such as age, height, smoking status, and atopy, had no significant influence on the models.

It is not clear, however, which agent(s) caused the observed lung function changes because the ANFO workers were significantly more highly exposed to many of the agents measured (total dust, respirable dust, alpha-quartz, volatile organic compounds, oil mist, oil vapors, formaldehyde, and nitrogen dioxide) when compared with the other two groups of tunnel workers. In addition, the exposure of these tunnel workers was low to moderate as compared with the Norwegian occupational exposure limits (3-40\% of the limits) (25). Of these components only the occupational exposure limit of nitrogen dioxide is based on airway obstruction.

Nitrogen dioxide is generated from both diesel-powered machines and blasting. We found in our study that the ANFO workers in contact with blasting fumes had substantial peak exposures to nitrogen dioxide $(>10$ ppm) and experienced such peaks fairly often (28\% of the measurements). The maximum observed peak value was $20 \mathrm{ppm}$ for a 2-minute averaging period, which is 10 times the Norwegian occupational exposure limit of $2 \mathrm{ppm}$ (which is a ceiling limit). We did not find lung function decreases among the SSE workers, who had much lower peak exposures to nitrogen dioxide than the ANFO workers. Søstrand et al (12) made stationary measurements of nitrogen dioxide and found peak values ranging from 14 to $29 \mathrm{ppm}$ when using ANFO as the explosive. Peak values with the use of SSE ranged from 1 to $3 \mathrm{ppm}$. In our study diesel-powered machinery was used in all the tunnels. The difference in the exposure levels of nitrogen dioxide between the ANFO and SSE workers was therefore likely due to the different explosives being used. In human challenge studies lung function has been found to be affected after nitrogen dioxide exposure of $1.5 \mathrm{ppm}$ for 3 hours (14), and increases in airway resistance have been reported at concentrations of 5-8 ppm over both short (5-minute) and longer (1-2 hours) exposures (26). Our results corroborate these findings. However, as continuous measurements of agents other than nitrogen dioxide and carbon monoxide were not made, exposure peaks of other agents cannot be excluded as the cause of the lung function changes.

Diesel exhaust is comprised of various chemical components that are potential health hazards (the oxides of nitrogen, the sulfur oxides, hydrocarbons, and particulate matter) (27). Rudell et al (28) has shown that exposure to diesel exhaust (characterized by an arithmetic mean exposure to nitrogen dioxide of $1.2 \mathrm{ppm}$ ) for 1 hour can induce bronchoalveolar inflammation in healthy human volunteers. However, Gamble et al (29) did not find any association between exposure to diesel exhaust during one workshift at nitrogen dioxide concentrations below $1.5 \mathrm{ppm}$ and acute reductions in the pulmonary function of bus garage workers. The study suggested that nitrogen dioxide and particles in diesel exhaust were below the threshold for producing a measurable reduction in lung function, and the finding is consistent with our results, which showed no effects among the SSE workers, who generally had nitrogen dioxide levels of $<1.5 \mathrm{ppm}$. We did not measure diesel exposures, but we did measure elemental carbon as a marker 
of diesel exhaust at another tunnel site (1). A geometric mean exposure to elemental carbon of $160 \mu \mathrm{g} / \mathrm{m}^{3}$ was found. At this tunnel site the same type and number of diesel-powered machines were used, and the tunnels were excavated using the same technology as in our study. It is therefore possible that the exposure of ANFO and SSE workers to diesel exhaust is similar. Because no major lung function changes were observed among the SSE workers, exposure to diesel exhaust does not appear to explain the observed differences in lung function between the ANFO and SSE workers.

It is unlikely that carbon monoxide has any direct effects on lung tissue except for the extremely high concentrations associated with carbon monoxide poisoning (30). Volatile organic compounds, which include oil vapors, were reported to have no effects on lung function in a human challenge study at levels of $25-50 \mathrm{mg} / \mathrm{m}^{3}$ (31), but another study found inflammatory effects in the upper airways (32). Effects on lung function from formaldehyde exposure have been demonstrated at levels of $0.3-1.2$ ppm (33-36). As levels of the volatile organic compounds were 5- to 10-fold lower and the formaldehyde levels were 20 - to- 40-fold lower in our study, volatile organic compounds and formaldehyde would not appear to be a likely cause of the observed lung function changes.

There was a small, but significant difference in the exposure to total dust between the ANFO and outdoor workers. A significant difference was also found between the total dust levels of the SSE and outdoor workers, but with no significant difference in lung function. There was little difference between the exposure levels of the two groups. For this reason, and because of the low levels measured, we do not believe that total dust can explain the decrease in lung function in this study.

The other measured exposures that are known to affect lung function are respirable dust, alpha-quartz (37), and oil mist $(18,38)$. The ANFO workers were exposed to higher levels of these three agents when they were compared with the other groups. With respect to the occupational exposure limits, the measured levels of the agents were low (all three being less than one-third of the occupational exposure limit). We cannot, however, rule out the possibility that these agents contribute to the observed decreases in lung function.

It is not known if the temporary lung function changes observed among these workers can also lead to chronic changes because the workers' lung function values returned to the baseline levels after an exposure-free period. However, in a previous study we found that tunnel workers were at increased risk of chronic obstructive pulmonary disease (6). Repeated exposures to nitrogen dioxide have been shown to result in neutrophilic inflammation in the lower airways (16). It is therefore possible that such exposure could lead to a chronic decrease in lung function.
In conclusion, tunnel workers using ANFO as an explosive showed temporary lung function reduction, whereas tunnel workers using SSE showed no significant change in lung function. Although the ANFO workers had higher exposures to a variety of substances, the most likely explanation for the observed lung function changes was peak exposures to nitrogen dioxide. Exposure to diesel exhaust was not a likely cause of the observed lung function changes.

\section{Acknowledgments}

We thank the construction workers for participating in the study and the staff of the National Institute of Occupational Health for their assistance with the analytical work. The project received financial support from the Working Environment Fund of the Confederation of Norwegian Business and Industry.

\section{References}

1. Bakke B, Stewart P, Ulvestad B, Eduard W. Dust and gas exposure in tunnel construction work. Am Ind Hyg Assoc J. In press.

2. Bavley H. Some environmental aspects in the construction of the city tunnel. Ind Hyg Q 1950;11:125—29.

3. Burns C, Ottoboni F, Mitchell HW. Health hazard and heavy construction. Ind Hyg J 1962;23:273-81.

4. Sullivan PA, Bang KM, Hearl FJ, Wagner GR. Respiratory disease risks in the construction industry. Occup Med 1995;10:313-34.

5. Ringen K, Seegal J, Englund A. Safety and health in the construction industry. Annu Rev Public Health 1995;16: $165-88$.

6. Ulvestad B, Bakke B, Melbostad E, Fuglerud P, Kongerud J, Lund MB. Tunnel workers are at increased risk of obstructive pulmonary disease. Thorax 2000;55:277-82.

7. International Agency for Research on Cancer (IARC). Diesel and gasoline engine exhausts and some nitroarenes. Lyon: IARC, 1989:1-458. IARC monographs on the evaluation of carcinogenic risks to humans, vol 46.

8. Blomberg A. Airway inflammatory and antioxidant responses to oxidative and particulate air pollutants - experimental exposure studies in humans. Clin Exp Allergy 2000;30:310 17.

9. Ulfvarson U, Alexandersson R, Dahlquist M, Ekholm U, Bergström B. Pulmonary function in workers exposed to diesel exhaust: the effect of control measures. Am J Ind Med 1991;19:283-89.

10. Ulfvarson U, Alexandersson R, Aringer L, Svensson E, Hedenstierna G, Hogstedt C, et al. Effects of exposure to vehicle exhaust on health. Scand J Work Environ Health 1987;13:505-12.

11. Scheepers PTJ, Bos RP. Combustion of diesel fuel from a toxicological perspective. Int Arch Occup Environ Health 
1992;64:149—61.

12. Søstrand P, Lian K, Myran T. The contribution of inorganic gases from diesel exhaust and from the blasting cloud during excavation of a tunnel. Occup Hyg 1997;4:1-13.

13. World Health Organization (WHO). Nitrogen oxides. 2nd ed. Geneva: WHO, 1997. Environmental health criteria, no 188.

14. Frampton MW, Morrow PE, Cox C, Gibb FR, Speers DM, Utell MJ. Effects of nitrogen dioxide exposure on pulmonary function and airway reactivity in normal humans. Am Rev Respir Dis 1991;143:522_-7.

15. Blomberg A, Krishna MT, Bocchino V, Biscione GL, Shute JK, Kelly FJ, et al. The inflammatory effects of $2 \mathrm{ppm} \mathrm{NO}_{2}$ on the airways of healthy subjects. Am J Respir Crit Care Med 1997;156:418-24.

16. Blomberg A, Krishna MT, Helleday R, Soderberg M, Ledin MC, Kelly FJ, et al. Persistent airway inflammation but accommodated antioxidant and lung function responses after repeated daily exposure to nitrogen dioxide. Am J Respir Crit Care Med 1999;159:536-43.

17. Vallyathan V, Castranova V, Pack D, Leonard S, Shumaker J, Hubbs AF, et al. Freshly fractured quartz inhalation leads to enhanced lung injury and inflammation: potential role of free radicals. Am J Respir Crit Care Med 1995;152:1003—9.

18. Svendsen K, Hilt B. Lung function disturbances and chest Xray abnormalities among marine engineers. Am J Ind Med 1999;35:590-4.

19. Massin N, Bohadana AB, Wild P, Goutet P, Kirstetter H, Toamain JP. Airway responsiveness, respiratory symptoms, and exposures to soluble oil mist in mechanical workers. Occup Environ Med 1996;53:748-52.

20. Chaiken RF, Cook EB, Ruhe TC. Toxic fumes from explosives: ammonium nitrate - fuel oil mixtures. Washington (DC): International Bureau of Mines, 1974. Report of investigations, no 7867.

21. Ulvestad B, Lund MB, Bakke B, Djupesland PG, Kongerud $\mathrm{J}$, Boe J. Exposure to gases and dust in underground construction work is associated with signs of upper and lower airway inflammation. Eur Respir J. In press.

22. American Thoracic Society. Standardization of spirometry1987 update. Am Rev Respir Dis 1987;136:1285-98.

23. Quanjar PH, Tammeling GJ, Cotes JE. Standardized lung function testing. Eur Respir J 1993;10:1683-93.

24. Eriksson NE. Allergy screening with Phadiatop and CAP Phadiatop in combination with a questionnaire in adults with asthma and rhinitis. Allergy 1990;45:285-92.

25. Norwegian Labor Inspection Authority. Norwegian list of occupational exposure limits. Oslo: Norwegian Labor Inspection Authority, 1996. No 361.

26. Von Nieding G, Wagner HM, Krekeler H, Loellgen H, Fries W, Beuthan A. Controlled studies of human exposure to single and combined action of $\mathrm{NO}_{2}, \mathrm{O}_{3}$, and $\mathrm{SO}_{2}$. Int Arch Occup Environ Health 1979;43:195-210.

27. Morgan WKC, Reger RB, Tucker DM. Health effects of diesel emissions. Ann Occup Hyg 1997;41:643-58.

28. Rudell B, Blomberg A, Helleday R, Ledin MC, Lundbäck B, Stjernberg N, et al. Bronchoalveolar inflammation after exposure to diesel exhaust: comparison between unfiltered and particle trap filtered exhaust. Occup Environ Med 1999; 56:527-34.

29. Gamble J, Jones W, Minshall S. Epidemiological-environmental study of diesel bus garage workers: acute effects of $\mathrm{NO}_{2}$ and respirable particulate on the respiratory system. Environ Res 1987;42:201-14.

30. World Health Organization (WHO). Carbon monoxide. 2nd ed. Geneva: WHO, 1999. Environmental health criteria, no 213.

31. Pappas GP, Herbert RJ, Henderson W, Koenig J, Stover B, Barnhart S. The respiratory effects of volatile organic compounds. Int J Occup Environ Health 2000;6:1—8.

32. Koren HS, Graham DE, Devlin RB. Exposure of humans to a volatile organic mixture, III: inflammatory response. Arch Environ Health 1992;47:39—44.

33. Alexandersson R, Hedenstierna G. Pulmonary function in wood workers exposed to formaldehyde: a prospective study. Arch Environ Health 1989;44:5-11.

34. Alexandersson R, Hedenstierna G. Respiratory hazards associated with exposure to formaldehyde and solvents in acidcuring paints. Arch Environ Health 1988;43:222-7.

35. Malaka T, Kodama AM. Respiratory health of plywood workers occupationally exposed to formaldehyde. Arch Environ Health 1990;45:288-94.

36. Holness DL, Nethercott JR. Health status of funeral service workers exposed to formaldehyde. Arch Environ Health 1989;44:222-8.

37. Humerfelt S, Eide GE, Gulsvik A. Association of years of occupational quartz exposure with spirometric airflow limitation in Norwegian men aged 30-46 years. Thorax 1998;53:649-55.

38. Robertson AS, Weir DC, Burge PS. Occupational asthma due to oil mists. Thorax 1988;43:200—5.

Received for publication: 17 October 2000 